\title{
Simultaneous stable isotope analysis of methane and nitrous oxide on ice core samples
}

\author{
C. J. Sapart ${ }^{1}$, C. van der Veen ${ }^{1}$, I. Vigano ${ }^{1}$, M. Brass, ${ }^{1}$, R. S. W. van de Wal $^{1}$, M. Bock ${ }^{2}$, H. Fischer ${ }^{2}$, T. Sowers ${ }^{3}$, \\ C. Buizert ${ }^{4}$, P. Sperlich ${ }^{4}$, T. Blunier ${ }^{4}$, M. Behrens ${ }^{5}$, J. Schmitt ${ }^{2}$, B. Seth ${ }^{2}$, and T. Röckmann ${ }^{1}$ \\ ${ }^{1}$ Institute for Marine and Atmospheric research Utrecht, Utrecht Univ., Princetonplein 5, 3584CC Utrecht, The Netherlands \\ ${ }^{2}$ Climate and Environmental Physics, Physics Institute and Oeschger Centre for Climate Change Research, Univ. of Bern, \\ Sidlerstrasse 5, 3012 Bern, Switzerland \\ ${ }^{3}$ Earth and Environmental Systems Institute, Geoscience, 237 Deike Building, Pennsylvania State Univ., University Park, \\ PA 16802, USA \\ ${ }^{4}$ Center for Ice and Climate, Niels Bohr Institute, Univ. of Copenhagen, Juliane Maries Vej 30, 2100 Copenhagen, Denmark \\ ${ }^{5}$ Alfred Wegener Institute for Polar and Marine Research, Am Handelshafen 12, 27570 Bremerhaven, Germany
}

Received: 16 June 2011 - Published in Atmos. Meas. Tech. Discuss.: 14 July 2011

Revised: 13 November 2011 - Accepted: 22 November 2011 - Published: 2 December 2011

\begin{abstract}
Methane and nitrous oxide are important greenhouse gases which show a strong increase in atmospheric mixing ratios since pre-industrial time as well as large variations during past climate changes. The understanding of their biogeochemical cycles can be improved using stable isotope analysis. However, high-precision isotope measurements on air trapped in ice cores are challenging because of the high susceptibility to contamination and fractionation.

Here, we present a dry extraction system for combined $\mathrm{CH}_{4}$ and $\mathrm{N}_{2} \mathrm{O}$ stable isotope analysis from ice core air, using an ice grating device. The system allows simultaneous analysis of $\delta \mathrm{D}\left(\mathrm{CH}_{4}\right)$ or $\delta^{13} \mathrm{C}\left(\mathrm{CH}_{4}\right)$, together with $\delta^{15} \mathrm{~N}\left(\mathrm{~N}_{2} \mathrm{O}\right)$, $\delta^{18} \mathrm{O}\left(\mathrm{N}_{2} \mathrm{O}\right)$ and $\delta^{15} \mathrm{~N}\left(\mathrm{NO}^{+}\right.$fragment $)$on a single ice core sample, using two isotope mass spectrometry systems. The optimum quantity of ice for analysis is about $600 \mathrm{~g}$ with typical "Holocene" mixing ratios for $\mathrm{CH}_{4}$ and $\mathrm{N}_{2} \mathrm{O}$. In this case, the reproducibility $(1 \sigma)$ is $2.1 \%$ for $\delta \mathrm{D}\left(\mathrm{CH}_{4}\right), 0.18 \%$ o for $\delta^{13} \mathrm{C}\left(\mathrm{CH}_{4}\right), 0.51 \%$ for $\delta^{15} \mathrm{~N}\left(\mathrm{~N}_{2} \mathrm{O}\right), 0.69 \%$ for $\delta^{18} \mathrm{O}\left(\mathrm{N}_{2} \mathrm{O}\right)$ and $1.12 \%$ for $\delta^{15} \mathrm{~N}\left(\mathrm{NO}^{+}\right.$fragment). For smaller amounts of ice the standard deviation increases, particularly for $\mathrm{N}_{2} \mathrm{O}$ isotopologues. For both gases, small-scale intercalibrations using air and/or ice samples have been carried out in collaboration with other institutes that are currently involved in isotope measurements of ice core air. Significant differences are shown between the calibration scales, but those offsets are consistent and can therefore be corrected for.
\end{abstract}

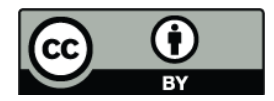

Correspondence to: C. J. Sapart

(c.j.sapart@uu.nl)

\section{Introduction}

The atmospheric mixing ratios of methane $\left(\mathrm{CH}_{4}\right)$ and nitrous oxide $\left(\mathrm{N}_{2} \mathrm{O}\right)$ have increased since pre-industrial time, which has contributed significantly to the increased radiative forcing since 1750 (Forster et al., 2007). Furthermore, for both gases, large variations are observed during past climate changes (Spahni et al., 2005). Numerous studies were performed to understand the atmospheric budget of $\mathrm{CH}_{4}$ and $\mathrm{N}_{2} \mathrm{O}$ in the past and to assess climate feedbacks of the natural sources in the climate system (Lelieveld et al., 1998; Dlugokencky et al., 1998, 2009; Bousquet et al., 2006; Etheridge et al., 1998; MacFarling Meure et al., 2006; Flückiger et al., 2002). Still the causes of variability, in particular of the natural sources, are not well understood. Isotope measurements can be used as a tool to distinguish contributions from individual sources (Brenninkmeijer et al., 2003) and changes in the sink strength. Measurements from the recent past have been obtained from atmospheric measurement networks (Quay et al., 1999; Miller et al., 2002), from archived air samples (Röckmann and Levin, 2005) and from firn air (Bräunlich et al., 2001; Ishijima et al., 2007). To obtain information on past atmospheric conditions, ice core air analyses are required. In that case, isotope measurements are particularly challenging, since only a small amount of air is available and extraction artifacts can bias the analysis. Nevertheless, the advent of continuous-flow isotope ratio mass spectrometry (IRMS) (Merritt et al., 1995), has led to the development of numerous analytical systems that only require small amounts of sample (e.g. Rice et al., 2001; Miller et

Published by Copernicus Publications on behalf of the European Geosciences Union. 


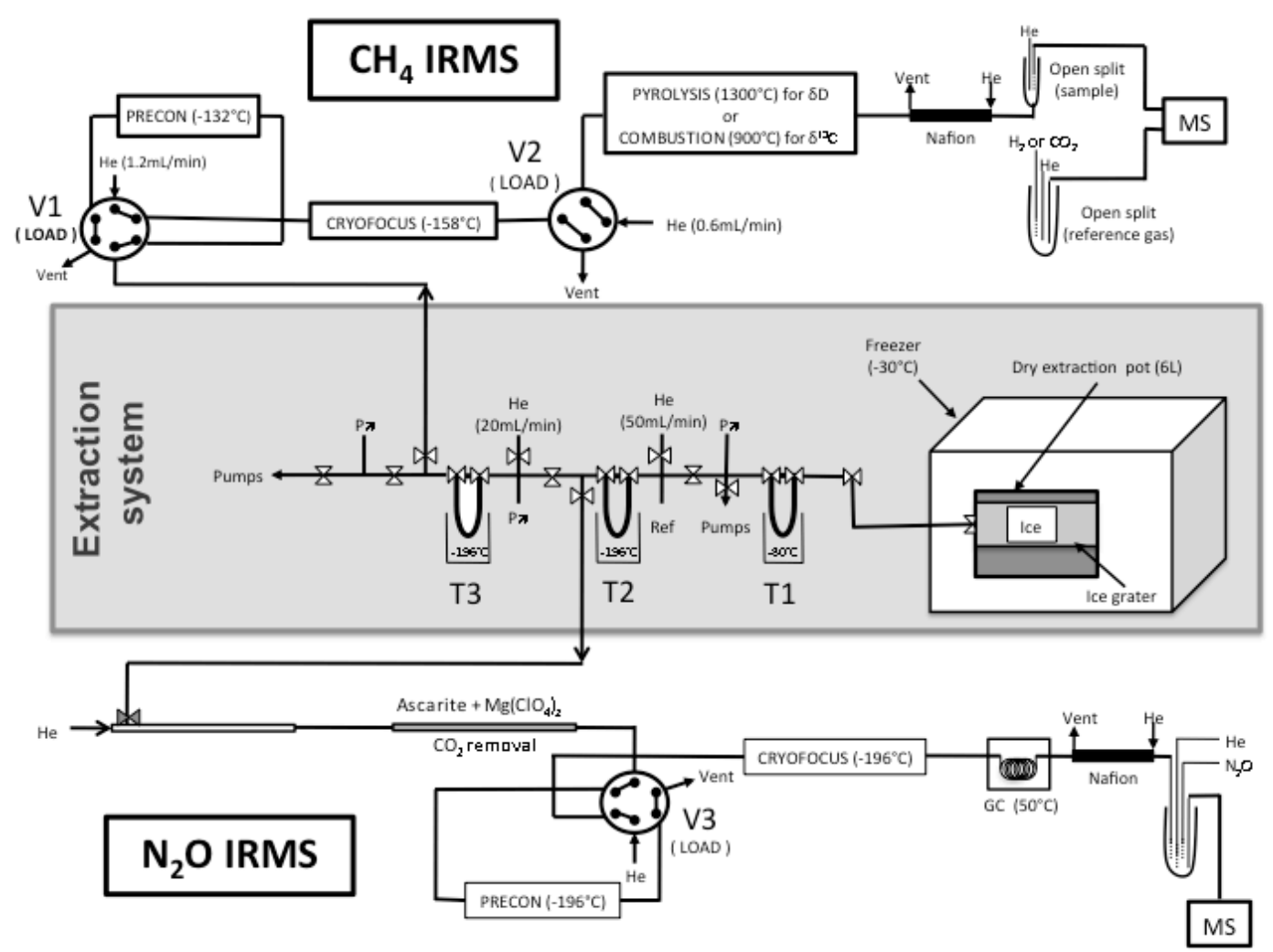

Fig. 1. Schematic set-up of the analytical system. The extraction system in the shaded box in the center consists of a glass line (12 mm o.d.) with manual valves. The connection between this glass line and the ice grater is made via a piece of flexible stainless steel bellows tubing. T1, T2 and T3 represent, respectively, a water trap, a $\mathrm{CO}_{2} / \mathrm{N}_{2} \mathrm{O}$ trap and a Hayesep trap where $\mathrm{CH}_{4}$ and air are adsorbed. V1, V2 and V3 represent multiport two-position Valco valves.

al., 2002; Röckmann et al., 2003b; Brass and Röckmann, 2010) and subsequent analytical systems for ice core analyses (Bernard et al., 2006; Schaefer et al., 2006; Ferretti et al., 2005; Sowers, 2001, 2006; Sowers et al., 2003; Bock et al., 2010b; Behrens et al., 2008). These developments have resulted in a number of interesting findings in the past years (Fischer et al., 2008; Mischler et al., 2009; Sowers, 2001, 2006, 2010; Sowers et al., 2003; Bernard et al., 2006; Ferretti et al., 2005; Bock et al., 2010a; Schäfer et al., 1998) which have, for example, ruled out a strong contribution of marine clathrate decomposition to paleoatmospheric methane changes as observed in ice core air.

Ice extraction systems exist as wet extraction systems (after Robbins et al., 1973; Craig and Chou, 1982), dry extraction systems (after Moor and Stauffer, 1984; Etheridge et al., 1988) and sublimation techniques (Gülük et al., 1997, 1998; Schmitt et al., 2011) each with their particular benefits and limitations. A drawback of most of the analytical systems published to date is that they can only measure one single compound per sample. Since ice air is limited and precious, we designed a system where at least two gases can be measured on one ice air sample, namely one isotope signature of $\mathrm{CH}_{4}\left(\delta \mathrm{D}\right.$ or $\delta^{13} \mathrm{C}$ ) and the complete isotopic composition of $\mathrm{N}_{2} \mathrm{O}\left(\delta^{15} \mathrm{~N}\left(\mathrm{~N}_{2} \mathrm{O}\right), \delta^{18} \mathrm{O}\left(\mathrm{N}_{2} \mathrm{O}\right)\right.$ and $\delta^{15} \mathrm{~N}\left(\mathrm{NO}^{+}\right.$fragment $\left.)\right)$. The new method is suited for ice samples of $200-800 \mathrm{~g}$ (for ice with mixing ratios of roughly $220-270 \mathrm{ppb}$ for $\mathrm{N}_{2} \mathrm{O}$ and 600-700 ppb for $\mathrm{CH}_{4}$ ) corresponding to a minimum of $\sim 14$ $17 \mathrm{ng}$ of $\mathrm{CH}_{4}$ and $\sim 15 \mathrm{ng}$ of $\mathrm{N}_{2} \mathrm{O}$ for Holocene ice, allowing a high temporal resolution $(\sim 20 \mathrm{yr})$ for Greenland ice core data. The amount of ice used is similar for $\mathrm{CH}_{4}$ and $30 \%$ smaller for $\mathrm{N}_{2} \mathrm{O}$ compared to already published datasets.

\section{Method}

\subsection{Experimental set-up}

The complete analytical system is schematically shown in Fig. 1. A dry extraction technique is coupled to two continuous-flow IRMS systems for simultaneous isotope analysis of $\mathrm{CH}_{4}$ and $\mathrm{N}_{2} \mathrm{O}$. These parts will be described in detail in the following subsections. 


\subsubsection{Extraction}

The extraction device consists of a 61 stainless steel (SS) pot equipped with a perforated SS cylinder with sharp edges, the so-called "ice-grater" (Etheridge et al., 1988), where an ice core sample is grated under its own weight by sliding back and forth over the grater. The grater fits precisely between bottom plate and lid of the extraction pot, to avoid interference in order to avoid metal-metal collisions, which may lead to $\mathrm{CH}_{4}$ contamination (Higaki et al., 2006). Moreover, the grater is coated with titanium nitride (TiN, BALINIT ${ }^{\circledR} \mathrm{A}$, Oerlikon Blazers) in order to harden, protect the grating surface and increase the lifetime of the grater. Following the introduction of the ice sample into the grating cylinder, the SS pot is sealed with a copper o-ring (conflat flange of $22 \mathrm{~cm}$ of diameter) and fixed in a shaking device inside a freezer at $-30^{\circ} \mathrm{C}$. From there, the pot can be evacuated to $10^{-3} \mathrm{mb}$ via the vacuum extraction system to remove laboratory air before grating starts. During the grating process, the shaker oscillates with a frequency up to $3 \mathrm{~Hz}$ (see below) and with an amplitude of about $6 \mathrm{~cm}$. After $20 \mathrm{~min}$ of grating following an optimized protocol (see below), $99 \%$ of an ice core piece of 200-800 $\mathrm{g}$ has been ground into flakes of 1 to $2 \mathrm{~mm}$ diameter.

After the grating, the SS pot is reconnected to the vacuum extraction system (Fig. 1) and the air evacuated from the ice is processed through Trap 1 (T1), which traps $\mathrm{H}_{2} \mathrm{O}$ at $-80^{\circ} \mathrm{C}$, and Trap 2 (T2), which traps $\mathrm{CO}_{2}, \mathrm{~N}_{2} \mathrm{O}$ and most higher molecular weight hydrocarbons at $-196^{\circ} \mathrm{C}$, to Trap 3 (T3). T1 and T2 are 2 U-shape tubes $(12 \mathrm{~mm}$ o.d., $L=250 \mathrm{~mm}) . \quad \mathrm{T} 3$ is a $\mathrm{U}$-shape tube $(35 \mathrm{~mm}$ o.d., $\mathrm{L}=250)$ filled with $\sim 40 \mathrm{ml}$ of Hayesep D (mesh 80/100, Alltech $\mathrm{GmbH}$, Germany), a molecular adsorbent, cooled to $-196^{\circ} \mathrm{C}$ in a liquid nitrogen bath. This trap acts as a cryopump adsorbing all the air (inclusive $\mathrm{CH}_{4}$ ) from the SS pot to T3 in $45 \mathrm{~min}$. After extraction, the $\mathrm{N}_{2} \mathrm{O}-\mathrm{CO}_{2}$ mixture trapped in $\mathrm{T} 2$ is flushed with $\mathrm{He}$ (He BIP 5.7 from Air Products) at ambient temperature to the $\mathrm{N}_{2} \mathrm{O}$ IRMS. Subsequently, $\mathrm{T} 3$ is heated to $60^{\circ} \mathrm{C}$ and its content is flushed by $\mathrm{He}$ to the $\mathrm{CH}_{4}$ IRMS. Both flushing units operate independently.

\subsubsection{Methane IRMS}

The $\mathrm{CH}_{4}$ IRMS system is a fully automated analytical set-up for $\delta \mathrm{D}\left(\mathrm{CH}_{4}\right)$ or $\delta^{13}\left(\mathrm{CH}_{4}\right)$ analyses (Brass and Röckmann, 2010). This system has been used for various laboratory and atmospheric studies in the past (Vigano et al., 2008, 2009, 2010; Keppler et al., 2006, 2008). For ice core-air measurements, the air trapped in $\mathrm{T} 3$ is flushed by He through a 2 position Valco 6 port valve $(\mathrm{V} 1)\left(\mathrm{VICI}^{\circledR}{ }^{\circledR}\right.$ AG International) to the preconcentration unit (PRECON) at a flow rate of $20 \mathrm{ml} \mathrm{min}^{-1}$. The PRECON of the $\mathrm{CH}_{4}$ IRMS system consists of a $1 / 8^{\prime \prime} \mathrm{SS}$ tube of which the central $6 \mathrm{~cm}$ are packed with Hayesep D (mesh 80/100, Alltech GmbH, Germany). At $-132^{\circ} \mathrm{C}$, the PRECON adsorbs $\mathrm{CH}_{4}$ while $\mathrm{O}_{2}$ and $\mathrm{N}_{2}$ are purged out to the vent. After 540s of preconcentration, the cooling is stopped, the PRECON system slowly warms up, and residual air is vented. Only shortly before the $\mathrm{CH}_{4}$ is released from the PRECON (at a temperature reading of $\sim-75^{\circ} \mathrm{C}$ ), $\mathrm{V} 1$ switches to "inject". The $\mathrm{CH}_{4}$ released is thus transferred to the CRYOFOCUS unit (Fig. 1), while other condensable gases are still retained on the Hayesep D. The cooling/heating system is explained in detail by Brass and Röckmann (2010). The CRYOFOCUS unit is a $1 / 16^{\prime \prime}$ gas chromatography (GC) column (Poraplot Q) cooled to $-158^{\circ} \mathrm{C}$ where $\mathrm{CH}_{4}$ is focused to obtain a narrow peak and remaining interferences are separated and removed (Brass and Röckmann, 2010). Following the CRYOFOCUS, $\mathrm{CH}_{4}$ is transferred through $\mathrm{V} 2$ to the conversion oven.

For $\delta \mathrm{D}$ measurements, $\mathrm{CH}_{4}$ is pyrolysed in an alumina $\left(\mathrm{Al}_{2} \mathrm{O}_{3}\right)$ tube $(0.8 \mathrm{~mm}$ inner diameter (i.d.), Length $(L)=360 \mathrm{~mm})$ at a temperature of $+1300^{\circ} \mathrm{C}$. During pyrolysis, $\mathrm{CH}_{4}$ is converted to hydrogen $\left(\mathrm{H}_{2}\right)$ and carbon (C). C is deposited on the inner surface of the alumina tube, which promotes an efficient pyrolysis and $\mathrm{H}_{2}$ production (Brass and Röckmann, 2010).

For $\delta^{13} \mathrm{C}$ measurements, $\mathrm{CH}_{4}$ is combusted to $\mathrm{CO}_{2}$ in an alumina tube $(1 \mathrm{~mm}$ i.d., $L=320 \mathrm{~mm})$ at $+900^{\circ} \mathrm{C}$. Three Nickel wires $(0.25 \mathrm{~mm}$ outer diameter (o.d.), Goodfellow, Cambridge Ltd., England) are used as catalysts and introduced into the tube. During each run, the combustion tube is flushed with $\mathrm{O}_{2}$ for $5 \mathrm{~s}$ to refresh the oxidant before $\mathrm{CH}_{4}$ reaches the reactor.

The simultaneous analysis of both $\delta \mathrm{D}$ and $\delta^{13} \mathrm{C}$ is not possible, thus the system is running either in the pyrolysis or in the combustion mode. Following the pyrolysis/combustion step, the sample is transferred via an open split interface (ThermoFinnigan Gas Bench II, Germany) to the mass spectrometer (ThermoFinnigan Delta plus XL, Germany).

\subsubsection{Nitrous oxide IRMS}

The $\mathrm{N}_{2} \mathrm{O}$ IRMS is a fully automated system based on (Röckmann et al., 2003b). The sample $\left(\mathrm{N}_{2} \mathrm{O}, \mathrm{CO}_{2}\right.$ and hydrocarbons) from the extraction system is transferred from $\mathrm{T} 2$ to the $\mathrm{N}_{2} \mathrm{O}$ PRECON in a He carrier gas flow at $50 \mathrm{ml} \mathrm{min}^{-1}$ for $400 \mathrm{~s}$. AscariteII ${ }^{\circledR}(\sim 8-20$ mesh, Aldrich chemistry, USA) is used to remove $>99.999 \%$ (Röckmann et al., 2003b) of the $\mathrm{CO}_{2}$ and magnesium perchlorate $\left(\mathrm{Mg}\left(\mathrm{ClO}_{4}\right)_{2}\right)$ removes the $\mathrm{H}_{2} \mathrm{O}$ formed in the reaction of $\mathrm{CO}_{2}$ with Ascarite. The $\mathrm{N}_{2} \mathrm{O}$ is then preconcentrated in a U-shaped SS tube $(1.2 \mathrm{~mm}$ i.d., $L=480 \mathrm{~mm})$ at $-196^{\circ} \mathrm{C}$, while the residual air is vented. After $400 \mathrm{~s}$, the sample is then transferred to the CRYOFOCUS, which consists of a fused silica capillary $(0.53 \mathrm{~mm}$ i.d., $L=460 \mathrm{~mm})$ cooled to $-196^{\circ} \mathrm{C}$. After cryofocusing, the $\mathrm{N}_{2} \mathrm{O}$ is purified from remaining $\mathrm{CO}_{2}$ and hydrocarbons on a GC column (PoraPLOT Q, $0.53 \mathrm{~mm}$ i.d., $L=25 \mathrm{~m})$ at $+30^{\circ} \mathrm{C}$ and then transferred via a Nafion ${ }^{\mathrm{TM}}$ dryer to a custom-made open split (Röckmann 
et al., 2003b) and to the mass spectrometer (ThermoFinnigan, Delta Plus XP, Germany). There, the ion masses $44,45,46,30$ and 31 are monitored for determination of $\delta^{15} \mathrm{~N}\left(\mathrm{~N}_{2} \mathrm{O}\right), \delta^{18} \mathrm{O}\left(\mathrm{N}_{2} \mathrm{O}\right)$ and the position dependent ${ }^{15} \mathrm{~N}$ signatures $\left(\delta^{15} \mathrm{~N}\left(\mathrm{NO}^{+}\right.\right.$fragment $\left.)\right)$as described in Brenninkmeijer and Röckmann (1999).

\subsection{Measurement procedure}

\subsubsection{Sample preparation and evacuation of the pot}

The ice sample is cut with a band saw to the desired size and shape. Subsequently, $\sim 2 \mathrm{~mm}$ of the surface of the sample is removed by microtoming. Next, the sample is weighed and inserted into the pre-cooled grating cylinder inside the SS pot. The pot is then immediately fixed to the shaking device inside the freezer at $-30^{\circ} \mathrm{C}$ and connected to the vacuum system via a $65 \mathrm{~cm}$ length SS flexible bellows tubing (C Swagelok). Evacuation is usually performed overnight and a vacuum of $10^{-3} \mathrm{mb}$ is reached. In the case 2 samples are measured per day, the pot containing a new ice sample is evacuated for at least $90 \mathrm{~min}$ in order to reach a pressure of $10^{-3} \mathrm{mb}$ as well.

\subsubsection{Blank and standard measurement}

To diagnose possible contamination and in order to monitor the stability of the analytical system, a blank and a standard measurement are performed before each ice sample. A sequence of measurement is blank-standard measurementblank-ice core sample-blank. The blank measurement before the ice core measurement (or before the standard measurement) is carried out in order to verify that neither $\mathrm{CH}_{4}$ nor $\mathrm{N}_{2} \mathrm{O}$ remains in $\mathrm{T} 2$ or $\mathrm{T} 3$, and that the system is cleaned and evacuated before starting the air measurements. The blank measurement after the "real" measurement (or after the standard measurement) is carried out to verify that the entire sample has been transferred from T2 and T3 to the IRMS systems and that the extraction system is evacuated properly. During the blank measurements, pure $\mathrm{He}$ carrier gas is flushed from $\mathrm{T} 2$ and $\mathrm{T} 3$ (heated to $+60^{\circ} \mathrm{C}$ ) to both IRMS systems and it is verified that neither $\mathrm{CH}_{4}$ nor $\mathrm{N}_{2} \mathrm{O}$ peaks appear in the system. Standard measurements are performed before the ice core sample with a blank measurement in between. The goal of the standard measurement is to verify a proper operation of T3 and to monitor the stability of the system. In a standard measurement, about $20-50 \mathrm{ml}$ of reference air

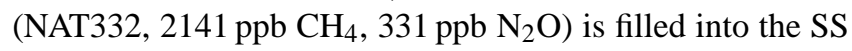
pot containing the ice sample for the subsequent run (the pot is evacuated beforehand). The reference air is then extracted like an ice air sample (see next section). The blank and standard measurement ensure that the system is thoroughly evacuated and in a reproducible state before starting with the ice sample.

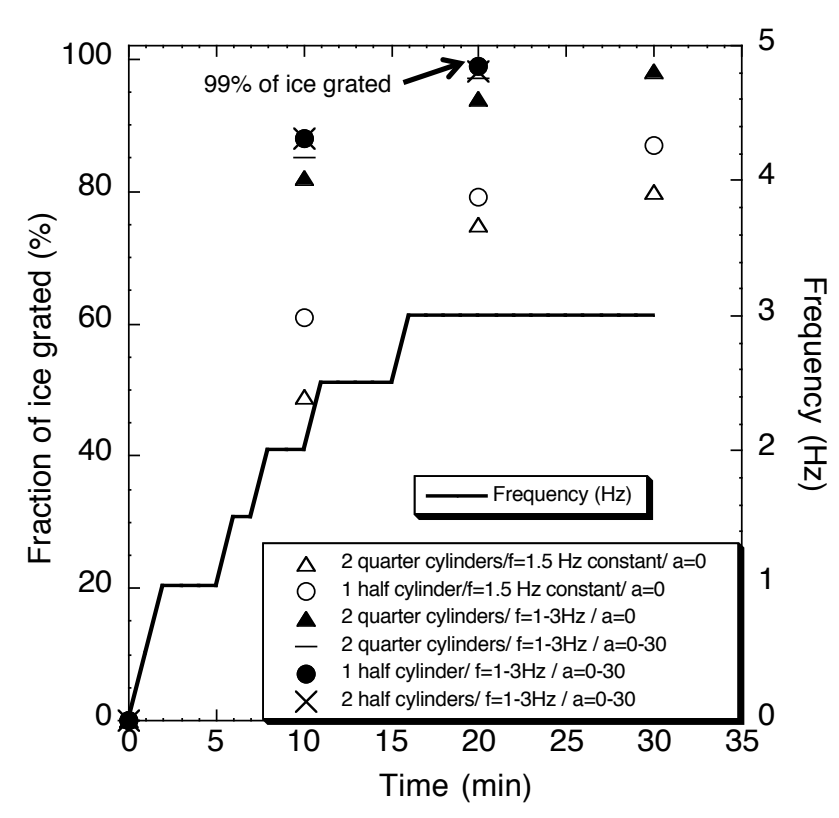

Fig. 2. Grating of twenty-two ice core samples of different length and different shapes at various frequencies and shaking angles (a). "a" is the angle between the horizontal plane and the cross section of the SS pot. The error estimate (smaller than the data-points) includes the error of the scale and the spread from repeated tests.

\subsubsection{Ice core air measurement}

Following the standard measurement, the evacuated SS pot is disconnected from the extraction line and ice grating starts. During the first $2 \mathrm{~min}$ the frequency is slowly increased to $1 \mathrm{~Hz}$ and then in several steps to $3 \mathrm{~Hz}$ (Fig. 2). This is done manually, and by listening, care is taken that the ice sample does not knock against the walls (lids and bottom) of the SS pot. After 20 min of shaking, the SS pot is reconnected to the glass-line and the transfer line is evacuated. T1 is cooled by an ethanol-liquid nitrogen mixture to $-80^{\circ} \mathrm{C}$ and $\mathrm{T} 2$ and $\mathrm{T} 3$ are cooled by liquid nitrogen to $-196^{\circ} \mathrm{C}$. After closing the valve between $\mathrm{T} 1$ and $\mathrm{T} 2$, the valve of the SS pot is opened and the pressure is measured with a MKS Baratron pressure gauge (accuracy: $0.05 \mathrm{mb}$ range $0-100 \mathrm{mb}$ ). The (STP) volume of air in the ice is calculated from the pressure and the volume of the pot and the mixing ratios is determined by comparing the peak area: sample air ratio in a sample to the same ratio in a calibrated reference gas. The extraction process starts by opening the valve between $\mathrm{T} 1$ and $\mathrm{T} 2$. The whole air sample is adsorbed on the Hayesep D in T3 within $45 \mathrm{~min}$; the valve after T3 is kept closed.

After $45 \mathrm{~min}$, the pressure reaches (behind a water trap) $10^{-3} \mathrm{mb}$ and does not decrease further. The valves separating the traps are closed and $\mathrm{T} 2$ is heated for $30 \mathrm{~s}$ in warm water $\left(+60^{\circ} \mathrm{C}\right.$ ) to release the trapped gases (mainly $\mathrm{N}_{2} \mathrm{O}$ and $\left.\mathrm{CO}_{2}\right)$. T3 is placed in a warm water $\left(+60^{\circ} \mathrm{C}\right)$ bath for at least 20 min to enable complete release of $\mathrm{CH}_{4}$. Thereafter, both 
IRMS systems are started simultaneously and the extracted samples are transferred to the IRMS systems. After isotope measurement of the ice air samples, the glass line is not evacuated, but the second blank measurement as described above is conducted to verify that all the air had been transferred to both IRMS systems.

After the measurement, the SS pot is opened, cleaned with lens paper, filled with new ice, sealed and reconnected to the shaker in the freezer for evacuation.

When the two IRMS systems are not analyzing blanks, standards or samples from the ice extraction system, they are automatically running air samples from laboratory reference air cylinders (NAT325 for the $\mathrm{CH}_{4}$ IRMS and NAT335 for the $\mathrm{N}_{2} \mathrm{O}$ IRMS, both filled with atmospheric air cylinders sampled in Groningen, NL) via the separate IRMS systems. Every reference air measurement lasts about $30 \mathrm{~min}$ and those runs are used for data correction (see Sect. 3.5) and quality control of the system.

\section{Optimization of the dry extraction system}

Several parameters were optimized for the new dry extraction system in order to ensure the most precise and reproducible stable isotope measurements.

\subsection{Grating efficiency}

We optimized the grating efficiency by adjusting the duration, position and frequency of the shaking and the shape of the ice sample in order to have the largest quantity of ice grated in the shortest amount of time. Twenty-two ice core samples (half or quarter cylinders) of 6 to $18 \mathrm{~cm}$ of length and between $200-800 \mathrm{~g}$ weight were introduced into the grater and shaken at frequencies varying from 0 to $3 \mathrm{~Hz}$ (Fig. 2). During the shaking tests, the pot was opened every $5 \mathrm{~min}$ and the remaining (i.e. non-grated) ice samples were weighed to evaluate the grating efficiency. Figure 2 shows the results of the grating tests. It appears that under optimal conditions, (with two half cylinders of $12 \mathrm{~cm}$ length and at a frequency of $0-3 \mathrm{~Hz}) 88 \%$ of the ice sample was grated after $10 \mathrm{~min}$ and $99 \%$ after $20 \mathrm{~min}$. The amount of ice introduced into the shaker is not a critical parameter, however, the shaking frequency and the position of the samples in the grater are important. When shaking is started at $3 \mathrm{~Hz}$, a strong knocking of the ice sample against the walls of the SS pot can be heard, which could potentially (but this was not clearly identified) damage the oxide layer of the SS surface and lead to $\mathrm{CH}_{4}$ production (Higaki et al., 2006). Furthermore, strong collisions with the wall break the ice sample into small pieces, which decreases the grating efficiency. Therefore, the frequency of shaking is increased slowly to $1 \mathrm{~Hz}$ during the first $2 \mathrm{~min}$, maintained at $1 \mathrm{~Hz}$ for 4 more min and then increased gradually again to $3 \mathrm{~Hz}$ (Fig. 2). Moreover, the SS pot can be fixed in the shaking device in different position from the horizontal to the vertical position. For the first $5-10 \mathrm{~min}$ of shaking, the pot stays in a horizontal position (angle $(a)=0$ ), thereafter it is rotated to an angle $(a)$ of $30^{\circ}$. This allows a more efficient grating of the small remaining pieces. For large samples $(>500 \mathrm{~g})$, the grating angle is maintained at $a=30^{\circ}$ during the entire grating process to prevent the ice to knock strongly against the lid of the SS pot. The typical diameter of the grated ice flakes is about $1-2 \mathrm{~mm}$ and $>97 \%$ of the air is extracted while grating bubbly ice. The grating efficiency is determined using the assumption that $10 \%$ of the ice volume is air which represents the average total air content for the type of ice used for the tests. So we compare the total air content with the calculated volume of air extracted as explained in Sect. 2.2.3.

\subsection{Extraction procedure}

Extraction of air from the grating pot is a critical step. Since the extraction takes a long time, it was decided not to pump through a $\mathrm{CH}_{4}$ adsorption agent with a vacuum pump, but to use a larger quantity of adsorption agent as cryopump. To find the most suitable adsorption agent, several grams of molecular sieve, activated carbon or Hayesep D were filled into separate $100 \mathrm{ml}$ glass bottles, thoroughly outgassed and used to adsorb different amounts of reference air from the SS pot. Hayesep D mesh 80/100, Alltech GmbH, Germany appears to be the most efficient and reproducible (in term of isotope ratio measurements) adsorbent. Tests with different mesh sizes were carried out and it appears that considering the relatively large amount of Haysep packed in T3, the largest mesh size was the most efficient, because the greater porosity allows a more efficient release of the air. Consequently, in the final design we used a glass-line provided with a $70 \mathrm{ml} \mathrm{U}$-shaped Hayesep D trap (T3).

The $\mathrm{N}_{2} \mathrm{O}$ is completely trapped in a U-shaped glass tube ( $12 \mathrm{~mm}$ o.d., $L=250 \mathrm{~mm}$ ) immersed in liquid nitrogen $\left(-196^{\circ} \mathrm{C}\right)$, and is released when heated to room temperature. It was verified that no $\mathrm{N}_{2} \mathrm{O}$ is trapped in $\mathrm{T} 1$ or $\mathrm{T} 3$ or remains in $\mathrm{T} 2$ after sample transfer to the isotope system by measuring the $\mathrm{N}_{2} \mathrm{O}$ mixing ratios from these traps after a normal sample analysis.

\subsection{Tests with bubble-free ice}

In order to test if potential contamination may occur during the grating-extraction process, nine bubble free (BF) ice samples were analyzed. The BF ice samples were produced by introducing Milli-Q water in plastic tubes of $15 \mathrm{~cm}$ length and $12 \mathrm{~cm}$ of diameter. A slow He flow was then bubbled through the water to purge out air. Subsequently, the plastic tube containing the water was slowly immersed in an ethanol-liquid nitrogen mixture at about $-80^{\circ} \mathrm{C}$ in order to slowly freeze the water from the bottom to the top. The BF ice samples were then cut with a band saw, microtomed and grated in the SS pot containing $20-50 \mathrm{ml}$ of reference air. 
Table 1. Results from tests with the extraction system. Each value represents the mean $\pm 1 \sigma$ standard deviation of $>40$ measurements of

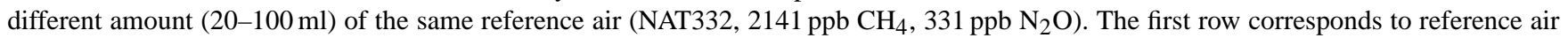
directly measured on the two IRMS systems. The second row corresponds to the measurement of reference air introduced into the SS pot and extracted as an ice core air sample.

\begin{tabular}{|c|c|c|c|c|c|}
\hline Description: & $\begin{array}{l}\delta^{13} \mathrm{C}\left(\mathrm{CH}_{4}\right) \\
\% \text { vs VPDB }\end{array}$ & $\begin{array}{l}\delta \mathrm{D}\left(\mathrm{CH}_{4}\right) \\
\% \text { vs SMOW }\end{array}$ & $\begin{array}{l}\delta^{15} \mathrm{~N}\left(\mathrm{~N}_{2} \mathrm{O}\right) \\
\% \text { ovs N2 }\end{array}$ & $\begin{array}{l}\delta^{18} \mathrm{O}\left(\mathrm{N}_{2} \mathrm{O}\right) \\
\% o \text { vs SMOW }\end{array}$ & $\begin{array}{l}\delta^{15} \mathrm{~N}\left(\mathrm{NO}^{+} \text {fragment }\right) \\
\% o \text { vs N2 }\end{array}$ \\
\hline $\begin{array}{l}\text { Reference air (NAT332) measured } \\
\text { directly on the IRMS }\end{array}$ & $-48.68 \pm 0.08$ & $-107.4 \pm 2.3$ & $6.91 \pm 0.10$ & $43.14 \pm 0.21$ & $-0.63 \pm 0.60$ \\
\hline $\begin{array}{l}\text { Reference air (NAT332) measured via } \\
\text { extraction system }\end{array}$ & $-48.55 \pm 0.18$ & $-104.3 \pm 2.8$ & $7.09 \pm 0.51$ & $43.68 \pm 0.79$ & $-0.11 \pm 0.32$ \\
\hline
\end{tabular}

It should be noted that although this BF ice does not contain air, it is less hard than deep ice core ice so the grating is not exactly identical. After the grating procedure, the reference air from the SS pot was extracted like an ice air sample and $\mathrm{CH}_{4}$ mixing ratios and stable isotope ratios were measured from T3 on a GC-Flame Ionization Detector (FID, GC8000 ${ }^{\text {top }}, \mathrm{CE}$ instruments ${ }^{\circledR}$ ) and on the IRMS system. In parallel, the reference air cylinder was analyzed directly on the GC-FID and on the IRMS system in order to verify that the extracted air had the same mixing ratio as measured directly from the cylinder. The results show that the differences in isotopic composition and mixing ratios, between the average values of bubble free ice measurement and the reference measurements is within the measurement uncertainty. This indicates that no significant contamination occurs during the grating-extraction process.

\subsection{System reproducibility}

More than forty reproducibility tests were conducted by extracting and analyzing between 20 and $100 \mathrm{ml}$ of reference air (NAT332, $2141 \mathrm{ppb} \mathrm{CH}_{4}$, atmospheric air cylinder from Groningen) from the SS pot either filled with leftover grated ice samples or empty. The test with leftover grated ice was done in order to verify that all the air released from the ice was adsorbed on T3, so that no air remained in the pot. NAT332 was regularly measured directly on both IRMS systems as well. The average differences between the isotope signature of NAT332 measured directly on both IRMS systems and extracted from the grating pot shows slight offsets of $0.13 \%$ or for $\delta^{13} \mathrm{C}\left(\mathrm{CH}_{4}\right), 0.5 \%$ or $\delta \mathrm{D}\left(\mathrm{CH}_{4}\right), 0.18 \%$ for $\delta^{15} \mathrm{~N}\left(\mathrm{~N}_{2} \mathrm{O}\right), 0.54 \%$ for $\delta^{18} \mathrm{O}\left(\mathrm{N}_{2} \mathrm{O}\right), 0.52 \%$ for $\delta^{15} \mathrm{~N}_{\left(\mathrm{NO}^{+}\right.}$ fragment) (Table 1). Those small offsets are constant and daily monitored with the standard measurements. For ice core samples, the reproducibility for different amounts of ice is presented in Table 2. The amount of air remains a limiting parameter for reliable $\mathrm{N}_{2} \mathrm{O}$ isotope and mixing ratio measurements. Air released from $200 \mathrm{~g}$ and $350 \mathrm{~g}$ of ice (with mixing ratios of $600-700 \mathrm{ppb}$ for $\mathrm{CH}_{4}$ and 220 $270 \mathrm{ppb}$ for $\mathrm{N}_{2} \mathrm{O}$ ) is enough for high precision (here high precision means that we reached or are beyond the precision of already published datasets for the same amount of ice) measurements for $\delta^{13} \mathrm{C}\left(\mathrm{CH}_{4}\right)$ and $\delta \mathrm{D}\left(\mathrm{CH}_{4}\right)$, respectively, but for this amount the precision is rather low for the $\mathrm{N}_{2} \mathrm{O}$ isotope signatures. An increase of the sample size to about $600 \mathrm{~g}$ leads to a strong reduction of the error also for $\mathrm{N}_{2} \mathrm{O}$ isotopologues (Table 2) which allows to reach or improve the precision of already published datasets (Sowers et al., 2002 and Bernard et al., 2006) using $40 \%$ less ice.

\subsection{Data correction}

The isotope analyses are performed on a ThermoFinnigan Delta plus XL IRMS (for $\mathrm{CH}_{4}$ isotopologues) and on a ThermoFinnigan XP IRMS (for $\mathrm{N}_{2} \mathrm{O}$ isotopologues). Running gas peaks of pure $\mathrm{CO}_{2}, \mathrm{H}_{2}$ and $\mathrm{N}_{2} \mathrm{O}$ bracket the sample peak for direct referencing to eliminate short-term shifts in IRMS performance. This raw $\delta$-value from the chromatogram is evaluated with the ISODAT software and is then compared to the daily mean value of reference air measurements on both IRMS systems to obtain the $\delta$ value of the sample versus the

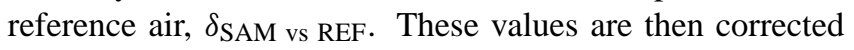
for non-linearity when needed (see below). The reference air cylinders have been independently calibrated versus international standards as explained in Brass and Röckmann (2010) and Kaiser et al. (2003).

Linearity tests are performed at least twice a week on both IRMS systems by running twenty-five analyses of various volumes ( 5 to $40 \mathrm{ml}$ for the $\mathrm{CH}_{4}$ IRMS and 20 to $333 \mathrm{ml}$ for the $\mathrm{N}_{2} \mathrm{O}$ IRMS) of reference air NAT335 (for $\mathrm{N}_{2} \mathrm{O}$ IRMS, $326 \mathrm{ppb}$ ) and NAT325 (for $\mathrm{CH}_{4}$ IRMS, $1970 \mathrm{ppb}$ ) covering the investigated sample range. Those linearity runs are used to monitor the quality of the analytical systems and the stability of the measurements for small peak areas.

The $\mathrm{N}_{2} \mathrm{O}$ IRMS system shows non-linearity trends for $\delta^{15} \mathrm{~N}\left(\mathrm{~N}_{2} \mathrm{O}\right)$ (Fig. 3a) and $\delta^{15} \mathrm{~N}\left(\mathrm{NO}^{+}\right.$fragment) (Fig. 3c), but not for $\delta^{18} \mathrm{O}\left(\mathrm{N}_{2} \mathrm{O}\right)$ (Fig. 3b). To solve this issue, about ten runs with reference air (NAT335) are performed before the ice core air measurement injecting $333 \mathrm{ml}$ of NAT335 reference air in order to reach peak areas corresponding to zone $\mathrm{C}$ (highest precision zone). The average of those ten runs is defined as $\delta_{\text {REF_C }}$. The ice core air sample is related to 
Table 2. System reproducibility. Five samples of similar ice were measured for each test. For each isotope signature, the first line gives the reproducibility for the minimum amount of ice necessary for reliable measurements and the second line gives the reproducibility for our preferred conditions, which is a trade-off between high precision and possible high temporal resolution.

\begin{tabular}{lccc}
\hline $\begin{array}{l}\text { Stable } \\
\text { isotope }\end{array}$ & $\begin{array}{c}\text { Gas amount } \\
(\mathrm{ng})\end{array}$ & $\begin{array}{c}\text { Ice amount } \\
600-700 \mathrm{ppb} \text { for } \mathrm{CH}_{4} \\
220-270 \mathrm{ppb} \text { for } \mathrm{N}_{2} \mathrm{O}\end{array}$ & $\begin{array}{c}1 \sigma \text {-reproducibility } \\
(\%)\end{array}$ \\
\hline$\delta^{13} \mathrm{C}\left(\mathrm{CH}_{4}\right)$ & $14 \pm 2$ & $200 \pm 38$ & $0.31 \pm 0.06$ \\
& $42 \pm 2$ & $600 \pm 54$ & $0.18 \pm 0.02$ \\
$\delta \mathrm{D}\left(\mathrm{CH}_{4}\right)$ & $21 \pm 2$ & $350 \pm 48$ & $2.9 \pm 0.8$ \\
& $42 \pm 2$ & $600 \pm 58$ & $2.1 \pm 0.2$ \\
$\delta^{15} \mathrm{~N}\left(\mathrm{~N}_{2} \mathrm{O}\right)$ & $10 \pm 1$ & $350 \pm 32$ & $0.92 \pm 0.11$ \\
& $17 \pm 1$ & $600 \pm 58$ & $0.51 \pm 0.09$ \\
$\delta^{18} \mathrm{O}\left(\mathrm{N}_{2} \mathrm{O}\right)$ & $10 \pm 1$ & $350 \pm 32$ & $1.08 \pm 0.23$ \\
& $17 \pm 1$ & $600 \pm 58$ & $0.69 \pm 0.14$ \\
$\delta^{15} \mathrm{~N}\left(\mathrm{NO}^{+}\right.$fragment $)$ & $10 \pm 1$ & $350 \pm 32$ & $1.63 \pm 0.31$ \\
& $17 \pm 1$ & $600 \pm 58$ & $1.12 \pm 0.48$ \\
\hline
\end{tabular}
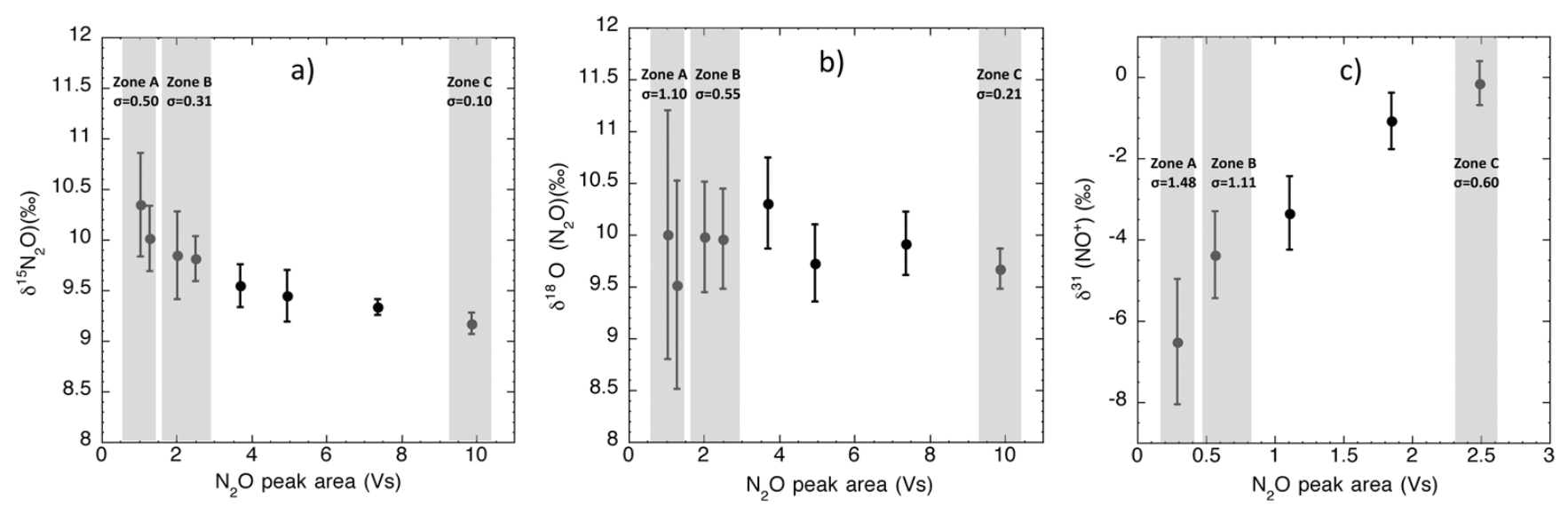

Fig. 3. Results from linearity tests for $\mathrm{N}_{2} \mathrm{O}$ isotopologues carried out twice a week during one month. Various amounts of reference air were introduced directly to the $\mathrm{N}_{2} \mathrm{O}$ IRMS system. Zone A corresponds to peak areas where the small ice core samples of B30 were measured $(350-480 \mathrm{~g})$. Zone B corresponds to the "optimal zone" where larger ice samples $(\sim 500-700 \mathrm{~g})$ are measured. Zone C corresponds to standard reference air measurements. (a) $\delta^{15} \mathrm{~N}\left(\mathrm{~N}_{2} \mathrm{O}\right)$ (b) $\delta^{18} \mathrm{O}\left(\mathrm{N}_{2} \mathrm{O}\right)(\mathbf{c}) \delta^{15} \mathrm{~N}\left(\mathrm{NO}^{+}\right.$fragment).

$\delta_{\text {REF_C }}$ in order to obtain $\delta_{\text {SAM vs REF }}$. In order to correct for the non-linearity, about ten reference air runs are performed covering exactly the same peak area as the ice sample measured beforehand (Fig. 3). The average of those ten runs is $\delta_{\text {REF_lin }}$. The linearity correction (Lin_corr) corresponds to $\delta_{\text {REF_C }}-\delta_{\text {REF_lin }}$. To obtain the final $\delta$ value, we add Lin_corr

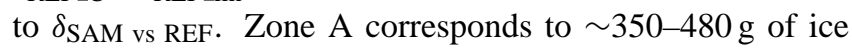
samples and zone B to $\sim 500-700 \mathrm{~g}$ of ice (Table 2). For $\mathrm{N}_{2} \mathrm{O}$ isotopologues, the error (standard deviation) decreases by at least $20 \%$ (depending on the isotope) from zone A to zone B. We preferentially measure ice samples in zone B, which is a compromise between good precision and economic use of ice (equivalent to possible high temporal resolution).
The $\mathrm{CH}_{4}$ IRMS system shows non-linearity patterns (Fig. 4a and b) as well. The correction procedure is similar for $\mathrm{N}_{2} \mathrm{O}$ isotopologues, but the number of runs before and after the ice core air run is about six. The amount of ice is less critical for $\mathrm{CH}_{4}$ isotopologues, because even when measuring ice in zone A, the reproducibility remains similar or better than already published datasets Behrens et al. (2008), Bock et al. (2010), Sowers et al. (2010).

\section{Intercomparison}

No internationally accepted isotope reference materials are currently available for the isotopic composition of $\mathrm{CH}_{4}$ and $\mathrm{N}_{2} \mathrm{O}$, so different laboratories use different local laboratory 

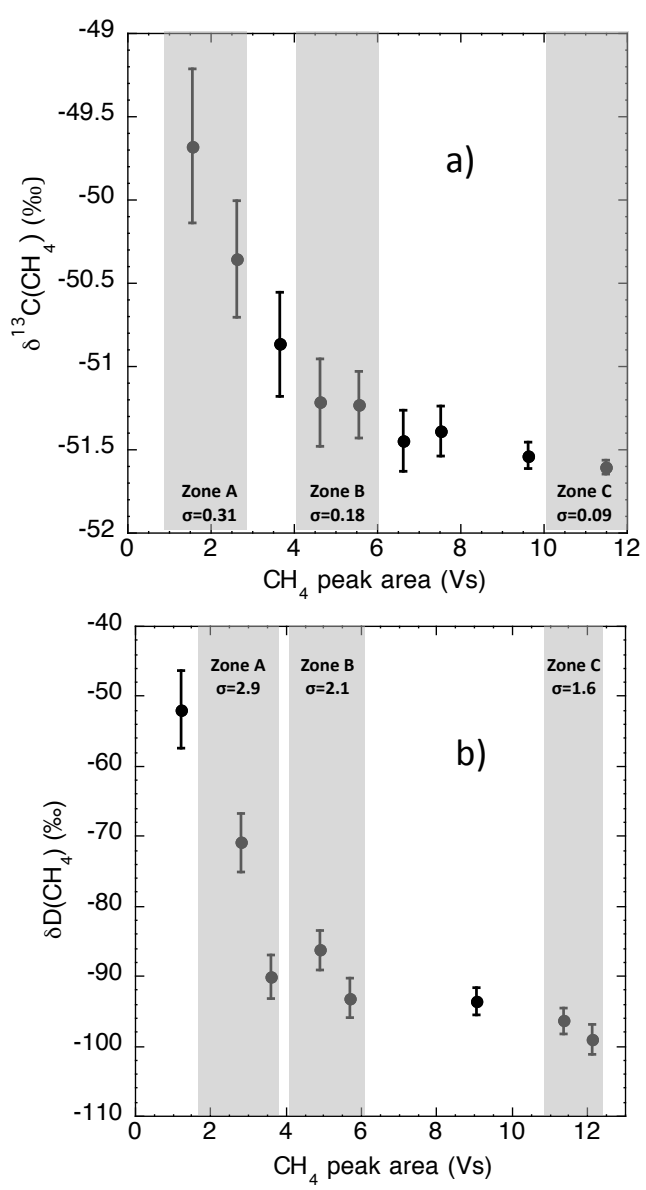

Fig. 4. Results from linearity tests for $\mathrm{CH}_{4}$ isotopologues carried out twice a week during one month. Various amounts of reference air were introduced directly to the $\mathrm{CH}_{4}$ IRMS system. Zone A corresponds to peak areas where the small ice core samples of B30 were measured (200-350 $\mathrm{g}$ for $\delta^{13} \mathrm{C}$ and $350-480 \mathrm{~g}$ for $\left.\delta \mathrm{D}\right)$. Zone $\mathrm{B}$ corresponds to the "optimal zone" where larger ice samples $(\sim 500$ $700 \mathrm{~g}$ ) are measured. Zone $\mathrm{C}$ corresponds to standard reference air measurements. (a) $\delta^{13} \mathrm{C}\left(\mathrm{CH}_{4}\right)$ (b) $\delta \mathrm{D}\left(\mathrm{CH}_{4}\right)$.

reference materials. Therefore, results from different laboratories are generally not directly comparable. Several laboratories are presently involved in isotope measurements of $\mathrm{CH}_{4}$ and $\mathrm{N}_{2} \mathrm{O}$ from the NEEM ice core (North Greenland Eemian Ice Drilling program). As a first step towards characterizing the offset between these laboratories, a small number of air and ice samples were exchanged between Utrecht University and the other laboratories. For $\mathrm{CH}_{4}$ isotope analysis, air and ice samples were exchanged with the Pennsylvania State University (PSU), the University of Bern (BERN) and the Alfred Wegener Institute for Polar and Marine Research in Bremerhaven (AWI). For $\mathrm{N}_{2} \mathrm{O}$ isotope analysis, three air samples were exchanged with the Center for Ice and Climate in Copenhagen (CIC). A larger intercomparison exercise, led by the PSU group, is currently being carried out with many more laboratories.

\subsection{Methane intercomparison}

Electropolished 21 stainless steel cans were used for the isotope analysis, similar to those used for air sampling on aircraft and subsequent isotope and trace gas analysis (Kaiser et al., 2006; Laube et al., 2010). For comparison with the PSU lab, three archived firn air samples were used. Two samples (IMAU402 and IMAU724) from the 1999 drilling at Dome C, Antarctica (Bräunlich et al., 2001) and one sample from Svalbard (IMAU490). The fourth sample corresponds to highly enriched $\mathrm{CH}_{4}$ (IMAU403). For the intercomparison with BERN two continental whole air samples (NAT325 and NAT332) were collected in Groningen, the Netherlands, and used as laboratory reference gases at IMAU. One of them (NAT332) contains a significant $\mathrm{CH}_{4}$ contamination (mixing ratio $2141 \mathrm{ppb}$ ). By combining firn air samples with clean and contaminated recent air samples, the air samples cover a range of $\sim 1.5 \%$ in $\delta^{13} \mathrm{C}$ and $\sim 35 \%$ o in $\delta \mathrm{D}$. The very enriched sample (IMAU403) has a ${ }^{13} \mathrm{C}$ content far outside the range of tropospheric values, but it has been included to assess potential differences in the $\delta$ scale, which is relevant since most laboratories only use a one-point calibration for $\mathrm{CH}_{4}$ isotopologues. The ice core samples were from Greenland (B30 core, $\sim 1750$ AD), and from Antarctica (B34 core, $\sim 250 \mathrm{AD}$ ), provided by AWI and analyzed by BERN, IMAU and AWI, respectively. In addition we used ice from the WAIS divide drilled in 2005 in Antarctica (WDCO5A, $\sim 1550 \mathrm{AD}$ ) provided by PSU and analyzed by PSU and IMAU.

Results of the $\mathrm{CH}_{4}$ intercomparison are summarized in Table 3. For the three firn air samples analyzed by IMAU and PSU (first three lines in Table 3), there is an average offset of $\delta^{13} \mathrm{C}\left(\mathrm{CH}_{4}\right)=0.28 \pm 0.03 \%$ and $\delta \mathrm{D}=12.1 \pm 1.5 \%$. This difference is very reproducible, indicating that it is likely due to an offset in calibration scales between the two laboratories. For the WAIS ice core samples (last line in Table 3), the difference is identical for $\delta \mathrm{D}(12.4 \%$ ), but it increases for $\delta^{13} \mathrm{C}$ to $0.51 \%$. This effect is larger than the reproducibility established for our new system. It is in the same direction, but slightly larger $(\sim 0.1 \%$ o $)$ than the difference between air measured directly and extracted from the ice grating device as shown in Table 1 . The difference of the IMAU $\delta^{13} \mathrm{C}\left(\mathrm{CH}_{4}\right)$ measurements and the results from BERN on ice core air is similar $(0.52 \%$ ), but the difference to AWI is much smaller $(0.11 \%$ ). Unfortunately, no air comparison samples are available for comparison between IMAU, and these two laboratories. For $\delta \mathrm{D}\left(\mathrm{CH}_{4}\right)$, the results from the IMAU and BERN systems agree very well for both air and ice measurements and the differences are well within the combined error, $4 \%$ and $6 \%$, respectively.

The results show that significant scale differences between the individual laboratories exist, which need to be accounted for when comparing data. The difference in offset between IMAU and PSU for air and ice samples indicates that the problem might aggravate when the ice extraction systems 
Table 3. Intercomparison of measurements made at IMAU with the new system and at other labs for air samples (six first lines) and ice samples (three last lines). 1 sigma standard deviations from $\mathrm{N}$-measurements are presented between brackets. All data are referenced to V-SMOW for $\delta \mathrm{D}\left(\mathrm{CH}_{4}\right)$ and V-PDB for $\delta^{13} \mathrm{C}\left(\mathrm{CH}_{4}\right)$.

\begin{tabular}{|c|c|c|c|c|c|c|c|c|}
\hline \multirow{2}{*}{$\begin{array}{l}\text { Sample } \\
\text { type }\end{array}$} & \multirow{2}{*}{$\begin{array}{l}\text { Sample ID } \\
\left(\mathrm{CH}_{4} \text { mix. ratio }\right)\end{array}$} & \multirow[t]{2}{*}{$\mathrm{N}$} & \multicolumn{2}{|c|}{$\delta^{13} \mathrm{C}\left(\mathrm{CH}_{4}\right)(\% o)$} & \multirow{2}{*}{$\begin{array}{l}\delta^{13} \mathrm{C}_{\mathrm{IMAU}}- \\
\delta^{13} \mathrm{C}_{\text {ex lab }} \\
\text { Ext. Lab }\end{array}$} & \multicolumn{2}{|c|}{$\delta \mathrm{D}\left(\mathrm{CH}_{4}\right)(\% o)$} & \multirow{2}{*}{$\begin{array}{l}\delta \mathrm{D}_{\mathrm{IMAU}^{-}} \\
\delta \mathrm{D}_{\text {ex_lab }} \\
\text { Ext. lab }\end{array}$} \\
\hline & & & IMAU & Ext. lab & & IMAU & Ext. lab & \\
\hline $\begin{array}{l}\text { Firn air } \\
\text { (Dome C) }\end{array}$ & $\begin{array}{l}\text { IMAU724 } \\
\text { (1604 ppb) }\end{array}$ & $>6$ & $\begin{array}{l}-48.66 \\
(0.18)\end{array}$ & $\begin{array}{l}-48.96 \\
(0.21)\end{array}$ & $\begin{array}{l}0.30 \% \\
\text { PSU }\end{array}$ & $\begin{array}{l}-75.8 \\
(0.4)\end{array}$ & $\begin{array}{l}-89.6 \\
(2.5)\end{array}$ & $\begin{array}{l}13.8 \% \\
\text { PSU }\end{array}$ \\
\hline $\begin{array}{l}\text { Firn air } \\
\text { Dome C }\end{array}$ & $\begin{array}{l}\text { IMAU402 } \\
(1701 \mathrm{ppb})\end{array}$ & $>6$ & $\begin{array}{l}-47.49 \\
(0.12)\end{array}$ & $\begin{array}{l}-47.78 \\
(0.13)\end{array}$ & $\begin{array}{l}0.29 \% \\
\text { PSU }\end{array}$ & $\begin{array}{l}-67.8 \\
(1.9)\end{array}$ & $\begin{array}{l}-78.9 \\
(1.3)\end{array}$ & $\begin{array}{l}11.1 \% \text { o } \\
\text { PSU }\end{array}$ \\
\hline $\begin{array}{l}\text { Firn air } \\
\text { Svalbard }\end{array}$ & $\begin{array}{l}\text { IMAU490 } \\
\text { (1821 ppb) }\end{array}$ & $>6$ & $\begin{array}{l}-47.32 \\
(0.14)\end{array}$ & $\begin{array}{l}-47.57 \\
(0.11)\end{array}$ & $\begin{array}{l}0.25 \% 0 \\
\text { PSU }\end{array}$ & $\begin{array}{l}-83.9 \\
(0.8)\end{array}$ & $\begin{array}{l}-95.3 \\
(1.7)\end{array}$ & $\begin{array}{l}11.4 \% \\
\text { PSU }\end{array}$ \\
\hline $\begin{array}{l}\text { Ambient } \\
\text { air }\end{array}$ & $\begin{array}{l}\text { NAT325 } \\
(1970 \mathrm{ppb})\end{array}$ & $>50$ & $\begin{array}{l}-47.24 \\
(0.18)\end{array}$ & I & I & $\begin{array}{l}-88.3 \\
(2.2)\end{array}$ & $\begin{array}{l}-89.4 \\
(1.7)\end{array}$ & $\begin{array}{l}1.1 \% o \\
\text { BERN }\end{array}$ \\
\hline $\begin{array}{l}\text { Ambient } \\
\text { air }\end{array}$ & $\begin{array}{l}\text { NAT332 } \\
(2141 \mathrm{ppb})\end{array}$ & $>50$ & $\begin{array}{l}-48.68 \\
(0.08)\end{array}$ & I & I & $\begin{array}{l}-107.4 \\
(2.3)\end{array}$ & $\begin{array}{l}-106.3 \\
(1.2)\end{array}$ & $\begin{array}{l}-1.1 \% \\
\text { BERN }\end{array}$ \\
\hline $\begin{array}{l}\text { Enriched } \\
\text { air }\end{array}$ & $\begin{array}{l}\text { IMAU403 } \\
(1906 \mathrm{ppb})\end{array}$ & $>6$ & $\begin{array}{l}-28.60 \\
(0.02)\end{array}$ & $\begin{array}{l}-28.11 \\
(0.07)\end{array}$ & $\begin{array}{l}-0.49 \% \\
\text { PSU }\end{array}$ & $\begin{array}{l}+23.5 \\
(0.4)\end{array}$ & $\begin{array}{l}+15.1 \\
(0.4)\end{array}$ & $\begin{array}{l}8.4 \% \\
\text { PSU }\end{array}$ \\
\hline $\begin{array}{l}\text { Ice } \\
\text { Greenland }\end{array}$ & $\begin{array}{l}\text { B30 } \\
(\sim 1750 \mathrm{AD})\end{array}$ & $>6$ & $\begin{array}{l}-48.44 \\
(0.27)\end{array}$ & $\begin{array}{l}-48.96 \\
(0.16)\end{array}$ & $\begin{array}{l}0.52 \% 0 \\
\text { BERN }\end{array}$ & $\begin{array}{l}-94.9 \\
(2.8)\end{array}$ & $\begin{array}{l}-94.7 \\
(3.7)\end{array}$ & $\begin{array}{l}0.2 \% \\
\text { BERN }\end{array}$ \\
\hline $\begin{array}{l}\text { Ice } \\
\text { Antarctica }\end{array}$ & $\begin{array}{l}\text { B34 } \\
(\sim 250 \mathrm{AD})\end{array}$ & $>5$ & $\begin{array}{l}-46.46 \\
(0.21)\end{array}$ & $\begin{array}{l}-46.57 \\
(0.13)\end{array}$ & $\begin{array}{l}0.11 \% \circ \\
\text { AWI }\end{array}$ & $\begin{array}{l}-80.5 \\
(3.1)\end{array}$ & I & I \\
\hline $\begin{array}{l}\text { Ice } \\
\text { Antarctica }\end{array}$ & $\begin{array}{l}\text { WDC05A } \\
(\sim 1550 \mathrm{AD})\end{array}$ & $\begin{array}{l}6\left({ }^{13} \mathrm{C}\right) \\
2(\mathrm{D})\end{array}$ & $\begin{array}{l}-47.10 \\
(0.08)\end{array}$ & $\begin{array}{l}-47.61 \\
(0.30)\end{array}$ & $\begin{array}{l}0.51 \% 0 \\
\text { PSU }\end{array}$ & $\begin{array}{l}-75.9 \\
(2.8)\end{array}$ & $\begin{array}{l}-88.3 \\
(4.0)\end{array}$ & $\begin{array}{l}12.4 \% \\
\text { PSU }\end{array}$ \\
\hline
\end{tabular}

are included in the intercomparison. This may be attributed to the difference between the extraction devices used. The IMAU data were obtained with a dry extraction system as described above and the other laboratories use different wet extraction techniques (e.g. Behrens et al., 2008; Bock et al., 2010b, Sowers, 2010).

Concerning the enriched sample (IMAU403), the offset between IMAU and PSU is not consistent with the average offset of the firn air samples. The change in offset is $0.8 \%$ over a range of $\sim 20 \%$. The results suggest that future international calibration efforts should aim for at least a two-point calibration strategy for $\mathrm{CH}_{4}$ isotopologues, where a scale difference can be calibrated like for water isotopologues (SMOW-SLAP-scale). The presented data are only a first step showing the existence of significant differences for $\delta^{13} \mathrm{C}\left(\mathrm{CH}_{4}\right)$.

The reported differences between different laboratories can be larger than the reported uncertainties of individual laboratories. This means that isotope variations along a polar ice core can be studied consistently and with high precision with one analytical system, but comparisons between datasets should take into account these differences.

An important issue is that possible offsets are constant and do not vary in time, which could be monitored by regularly measuring similar ice core samples. In addition, regular comparisons between wet and dry extraction methods may be used to assess long-term stability of the extraction procedure, and such measurements have been initiated in our laboratory.

\subsection{Nitrous oxide intercomparison}

For $\mathrm{N}_{2} \mathrm{O}$, no ice samples have been compared between laboratories yet, but three air cylinders (one with background tropospheric air and two with synthetic air mixtures) have been measured at least five times per cylinder by both IMAU and CIC for $\delta^{15} \mathrm{~N}\left(\mathrm{~N}_{2} \mathrm{O}\right)$ and $\delta^{18} \mathrm{O}\left(\mathrm{N}_{2} \mathrm{O}\right)$ (Fig. 5). The gases were selected in order to have a wide isotopic spread. The cylinder with tropospheric background air was sampled at the NEEM deep drilling site in July 2008. For the intercomparison study, the cylinder of NEEM tropospheric background air was used by both laboratories as the reference and isotopes are reported to be consistent with these predicted values. The mean difference between the two laboratories is $0.11 \%$ or $\delta^{15} \mathrm{~N}\left(\mathrm{~N}_{2} \mathrm{O}\right)$ and $0.05 \%$ for $\delta^{18} \mathrm{O}\left(\mathrm{N}_{2} \mathrm{O}\right)$, which demonstrates an excellent agreement between IMAU and CIC for air samples. Once the CIC ice system becomes operational, ice core air intercalibration will be performed. 

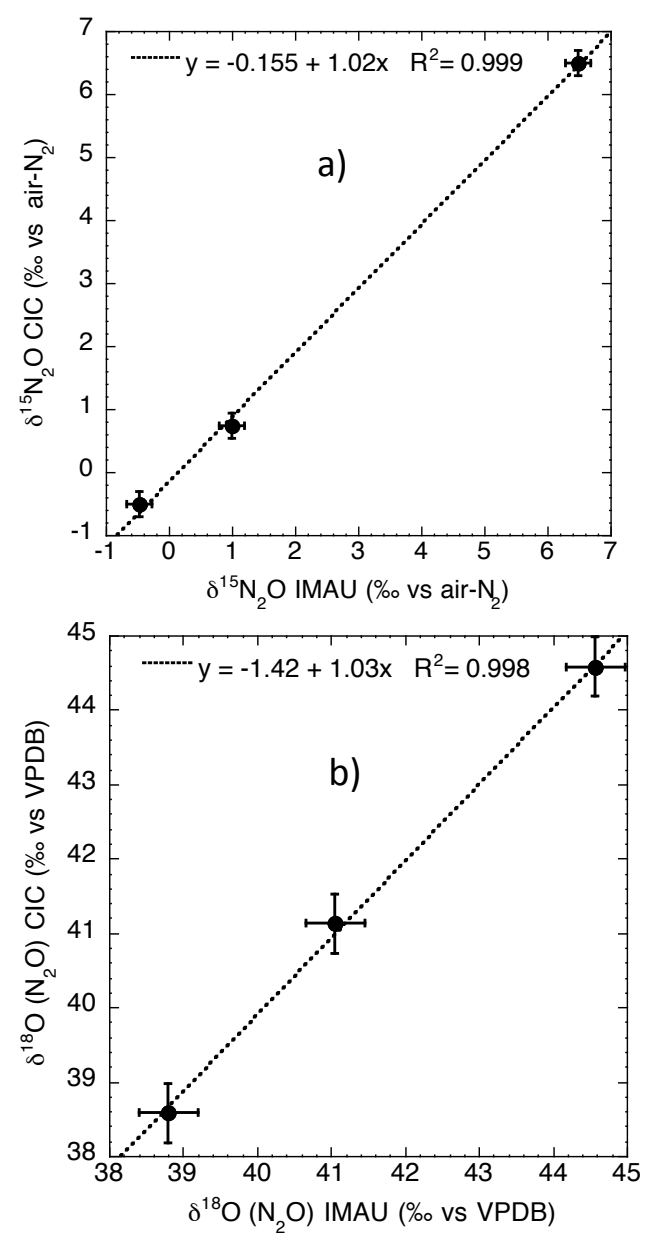

Fig. 5. $\mathrm{N}_{2} \mathrm{O}$ isotope results of three air cylinders measured at IMAU and CIC. (a) $\delta^{15} \mathrm{~N}$ (b) $\delta^{18} \mathrm{O}$. The dotted line represents the best fit.

\section{Conclusions}

A new dry extraction technique coupled to two IRMS systems for simultaneous $\mathrm{CH}_{4}$ and $\mathrm{N}_{2} \mathrm{O}$ isotope analysis has been developed for high-precision isotope measurements of ice core air. The minimum amount of preindustrial ice (with $\mathrm{CH}_{4}$ mixing ratios of about $600-700 \mathrm{ppb}$ and $\mathrm{N}_{2} \mathrm{O}$ mixing ratios of about 220-270 ppb) necessary for measurements of both gases is $350 \mathrm{~g}$, but in order to increase reproducibility, we preferentially measure samples of about $600 \mathrm{~g}$. For these amounts, the reproducibility is $2.1 \%$ of $\delta \mathrm{D}\left(\mathrm{CH}_{4}\right)$, $0.18 \%$ o for $\delta^{13} \mathrm{C}\left(\mathrm{CH}_{4}\right), 0.51 \%$ o for $\delta^{15} \mathrm{~N}\left(\mathrm{~N}_{2} \mathrm{O}\right), 0.69 \%$ of $\delta^{18} \mathrm{O}\left(\mathrm{N}_{2} \mathrm{O}\right)$ and 1.12 for $\delta^{15} \mathrm{~N}\left(\mathrm{NO}^{+}\right.$fragment). Possible small offsets during the extraction of air from the grating device are smaller than the presently existing uncertainties of the $\mathrm{CH}_{4}$ and $\mathrm{N}_{2} \mathrm{O}$ isotope scales for all signatures. Results from a small-scale intercalibration exercise for air and ice samples with five external laboratories (BERN, PSU, CIC and AWI) reveal significant offsets between the laboratories. Future attempts for harmonization of the $\mathrm{CH}_{4}$ isotope scale should provide at least a two-point calibration scale. Despite these open issues on calibration, the excellent reproducibility will allow the new analytical system to investigate in detail the past atmospheric budget of $\mathrm{CH}_{4}$ and $\mathrm{N}_{2} \mathrm{O}$ with relatively high temporal resolution allowing reconstructing changes in the sources and sinks.

Acknowledgements. We would like to acknowledge the Dutch Science Foundation (NWO) for funding (Projects: 851.30.020 \& 865.07.001).

Edited by: D. Griffith

\section{References}

Behrens, M., Schmitt, J., Richter, K. U., Bock, M., Richter, U. C., Levin, I., and Fischer, H.: A gas chromatography/combustion/isotope ratio mass spectrometry system for high-precision delta $\delta^{13} \mathrm{C}$ measurements of atmospheric $\mathrm{CH}_{4}$ extracted from ice core samples, Rapid Commun. Mass Spectrom., 22, 3261-3269, doi:10.1002/rcm.3720, 2008.

Bernard, S., Röckmann, T., Kaiser, J., Barnola, J.-M., Fischer, H., Blunier, T., and Chappellaz, J.: Constraints on $\mathrm{N}_{2} \mathrm{O}$ budget changes since pre-industrial time from new firn air and ice core isotope measurements, Atmos. Chem. Phys., 6, 493-503, doi:10.5194/acp-6-493-2006, 2006.

Bock, M., Schmitt J., Möller, L., Spahni R., Blunier T., and Fischer H.: Hydrogen isotopes preclude marine hydrate $\mathrm{CH}_{4}$ emissions at the onset of Dansgaard-Oeschger events, Science, 328, 16861689, doi:10.1126/science.1187651, 2010a.

Bock, M., Schmitt, J., Behrens, M., Moller, L., Schneider, R., Sapart, C., and Fischer, H.: A gas chromatography/pyrolysis/isotope ratio mass spectrometry system for highprecision $\delta \mathrm{D}$ measurements of atmospheric $\mathrm{CH}_{4}$ extracted from ice cores, Rapid Commun. Mass Spectrom., 24, 621-633, doi:10.1002/rcm.4429, 2010b.

Bousquet, P., Ciais, P., Miller, J. B., Dlugokencky, E. J., Hauglustaine, D. A., Prigent, C., Van der Werf, G. R., Peylin, P., Brunke, E. G., Carouge, C., Langenfelds, R. L., Lathiere, J., Papa, F., Ramonet, M., Schmidt, M., Steele, L. P., Tyler, S. C., and White, J.: Contribution of anthropogenic and natural sources to atmospheric $\mathrm{CH}_{4}$ variability, Nature, 443, 439-443, doi:10.1038/nature05132, 2006.

Brass, M. and Röckmann, T.: Continuous-flow isotope ratio mass spectrometry method for carbon and hydrogen isotope measurements on atmospheric methane, Atmos. Meas. Tech., 3, 17071721, doi:10.5194/amt-3-1707-2010, $2010 .$.

Bräunlich, M., Aballain, O., Marik, T., Jockel, P., Brenninkmeijer, C. A. M., Chappellaz, J., Barnola, J. M., Mulvaney, R., and Sturges, W. T.: Changes in the global atmospheric $\mathrm{CH}_{4}$ budget over the last decades inferred from $\delta^{13} \mathrm{C}$ and $\delta \mathrm{D}$ isotopic analysis of Antarctic firn air, J. Geophys. Res., 106, 20465-20481, doi:10.1029/2001JD900190, 2001.

Brenninkmeijer, C. A. M. and Röckmann, T.: Mass spectrometry of the intramolecular nitrogen isotope distribution of environmental $\mathrm{N}_{2} \mathrm{O}$ using fragment-ion analysis, Rapid Commun. Mass Spectrom., 13, 2028-2033, 1999.

Brenninkmeijer, C. A. M., Janssen, C., Kaiser, J., Röckmann, T., Rhee, T. S., and Assonov, S. S.: Isotope effects in the chem- 
istry of atmospheric trace gases, Chem. Rev., 103, 5125-5162, doi:10.1021/cr020644k, 2003.

Craig, H. and Chou, C. C.: Methane - the Record in Polar Ice Cores, Geophys. Res. Lett., 9, 1221-1224, 1982.

Dlugokencky, E. J., Masarie, K. A., Lang, P. M., and Tans, P. P.: Continuing decline in the growth rate of the atmospheric $\mathrm{CH}_{4}$ burden, Nature, 393, 447-450, doi:10.1038/30934, 1998.

Dlugokencky, E. J., Bruhwiler, L., White, J. W. C., Emmons, L. K., Novelli, P. C., Montzka, S. A., Masarie, K. A., Lang, P. M., Crotwell, A. M., Miller, J. B., and Gatti, L. V.: Observational constraints on recent increases in the atmospheric $\mathrm{CH}_{4}$ burden, Geophys. Res. Lett., 36, L18803, doi:18810.11029/12009g1039780, 2009.

Etheridge, D. M., Pearman, G. I., and Silva, F. D.: Atmospheric trace-gas variations as revealed by air trapped in an ice core from Law Dome, Antarctica, Ann. Glaciol., 10, 28-33, 1988.

Etheridge, D. M., Steele, L. P., Francey, R. J., and Langenfelds, R. L.: Atmospheric $\mathrm{CH}_{4}$ between $1000 \mathrm{AD}$ and present: Evidence of antropogenic emissions and climatic variability, J. Geophys. Res., 103, 15979-15993, 1998.

Ferretti, D., Miller, J., White, J., Etheridge, D., Lassey, K., Lowe, D., Allan, B., MacFarling, C., Dreier, M., Trudinger, C., and Ommen, T. V.: Unexpected changes to the global $\mathrm{CH}_{4}$ budget over the past 2000 years, Science, 309, 864-867, doi:10.1126/science.1115193, 2005.

Fischer, H., Behrens, M., Bock, M., Richter, U., Schmitt, J., Loulergue, L., Chappellaz, J., Spahni, R., Blunier, T., Leuenberger, M., and Stocker, T. F.: Changing boreal $\mathrm{CH}_{4}$ sources and constant biomass burning during the last termination, Nature, 452, 864867, doi:10.1038/nature06825, 2008.

Flückiger, J., Monnin, E., Stauffer, B., Schwander, J., Stocker, T. F., Chappellaz, J., Raynaud, D., and Barnola, J. M.: Highresolution Holocene $\mathrm{N}_{2} \mathrm{O}$ ice core record and its relationship with $\mathrm{CH}_{4}$ and $\mathrm{CO}_{2}$, Global Biogeochem. Cy., 16, 1010, doi:10.1029/2001GB001417, 2002.

Forster, P., Ramaswamy, V., Artaxo, P., Berntsen, T., Betts, R., Fahey, D. W., Haywood, J., Lean, J., Lowe, D. C., Myhre, G., Nganga, J., R. Prinn, Raga, G., Schulz, M., and Dorland, R. V.: Changes in Atmospheric Constituents and in Radiative Forcing, in: Climate Change 2007: The Physical Science Basis. Contribution of Working Group I to the Fourth Assessment Report of the Intergovernmental Panel on Climate Change, edited by: Solomon, S., Qin, D., Manning, M., Chen, Z., Marquis, M., Averyt, K. B., Tignor, M., and Miller, H. L., Cambridge University Press, Cambridge, United Kingdom and New York, NY, USA, 2007.

Güllük, T. and Slemr, F.: Simultaneous measurements of $\mathrm{CO}_{2}, \mathrm{CH}_{4}$ and $\mathrm{N}_{2} \mathrm{O}$ in air extracted by sublimation from Antarctica ice cores: Confirmation of the data obtained using other extraction, J. Geophys. Res., 103, 15971-15978, doi:10.1029/98JD00686, 1998.

Güllük, T., Wagner, H. E., and Slemr, F.: A high-frequency modulated tunable diode laser absorption spectrometer for measurements of $\mathrm{CO}_{2}, \mathrm{CH}_{4}, \mathrm{~N}_{2} \mathrm{O}$ and $\mathrm{CO}$ in air samples of few $\mathrm{cm}^{3}$, Rev. Sci. Instrum., 68, 230, doi:10.1063/1.1147814, 1997.

Higaki, S., Oya, Y., and Makide, Y.: Emission of $\mathrm{CH}_{4}$ from Stainless Steel Surface Investigate by using Tritium as a Radioactive Tracer, Chem. Lett., 35, 292, doi:10.1246/cl.2006.292, 2006.

IPCC: Climate Change 2007: The Physical Science Basis - Fourth
Assessment Report of the Intergovernmental Panel on Climate Change, Cambridge Univ. Press, New York, 2007.

Ishijima, K., Sugawara, S., Kawamura, K., Hashida, G., Morimoto, S., Murayama, S., Aoki, S., and Nakazawa, T.: Temporal variations of the atmospheric $\mathrm{N}_{2} \mathrm{O}$ concentration and its delta $\delta^{15} \mathrm{~N}$ and delta $\delta^{18} \mathrm{O}$ for the latter half of the 20th century reconstructed from firn air analyses, J. Geophys. Res.-Atmos., 112, D03305, doi:10.1029/2006JD007208, 2007.

Kaiser, J., Engel, A., Borchers, R., and Röckmann, T.: Probing stratospheric transport and chemistry with new balloon and aircraft observations of the meridional and vertical $\mathrm{N}_{2} \mathrm{O}$ isotope distribution, Atmos. Chem. Phys., 6, 3535-3556, doi:10.5194/acp6-3535-2006, 2006.

Keppler, F., Hamilton, J. T. G., Brass, M., and Röckmann, T.: $\mathrm{CH}_{4}$ emissions from terrestrial plants under aerobic conditions, Nature, 439, 187-191, doi:110.1038/nature04420, 2006.

Keppler, F., Hamilton, J. T. G., McRoberts, W. C., Vigano, I., Brass, M., and Röckmann, T.: Methoxyl groups of plant pectin as a precursor of atmospheric $\mathrm{CH}_{4}$ : evidence from deuterium labelling studies, New Phytol., 178, 808-814, doi:10.1111/j.14698137.2008.02411.x, 2008.

Laube, J. C., Martinerie, P., Witrant, E., Brenninkmeijer, C. A. M., Bolder, M., Röckmann., T., van der Veen, C., and Sturges, W. T.: Accelerating growth of HFC-227ea (1,1,1,2,3,3,3heptafluoropropane) in the atmosphere, Atmos. Chem. Phys., 10, 5903-5910, doi:10.5194/acp-10-5903-2010, 2010.

Lelieveld, J., Crutzen, P. J., and Dentener, F. J.: Changing concentration, lifetimes and climate forcing of atmospheric $\mathrm{CH}_{4}$, Tellus, 50B, 128-150, 1998.

MacFarling Meure, C., Etheridge, D., Trudinger, C., Steele, P., Langenfelds, R., Ommen, T. V., Smith, A., and Elkins, J.: Law Dome $\mathrm{CO}_{2}, \mathrm{CH}_{4}$ and $\mathrm{N}_{2} \mathrm{O}$ ice core records extended to 2000 years BP Geophys. Res. Lett., 33, L14810, doi:14810.11029/12006GL026152, 2006.

Merritt, D. A., Hayes, J. M., and Des Marais, D. J.: Carbon isotopic analysis of atmospheric $\mathrm{CH}_{4}$ by isotope-ratio-monitoring gas chromatography-mass spectrometry, J. Geophys. Res., 100 D, 1317/1326, doi:10.1029/94JD02689, 1995.

Miller, J. B., Mack, K. A., Dissly, R., White, J. W. C., Dlugokencky, E. J., and Tans, P. P.: Development of analytical methods and measurements of $\delta^{13} \mathrm{C}$ in atmospheric $\mathrm{CH}_{4}$ from the NOAA/CMDL global air sampling network, J. Geophys. Res., 107, 4178, doi:10.1029/2001JD000630, 2002.

Mischler, J. A., Sowers, T. A., Alley, R. B., Battle, M., McConnell, J. R., Mitchell, L., Popp, T., Sofen, E., and Spencer, M. K.: Carbon and hydrogen isotopic composition of $\mathrm{CH}_{4}$ over the last 1000 years, Global Biogeochem. Cy., 23, GB4024, doi:10.1029/2009GB003460, 2009.

Moor, E. and Stauffer, B.: A New Dry Extraction System for Gases in Ice, J. Glaciol., 30, 358-361, 1984.

Quay, P., Stutsman, J., Wilbur, D., Snover, A., Dlugokencky, E., and Brown, T.: The isotopic composition of atmospheric $\mathrm{CH}_{4}$, Global Biogeochem. Cy., 13, 445-461, doi:10.1029/1998GB900006, 1999.

Rice, A. L., Gotoh, A. A., Ajie, H. O., and Tyler, S. C.: High-precision continuous-flow measurement of $\delta^{13} \mathrm{C}$ and $\delta \mathrm{D}$ of atmospheric $\mathrm{CH}_{4}$, Anal. Chem., 73, 4104-4110, doi:10.1021/ac0155106, 2001.

Robbins, R. C., Cavanagh, L. A., and Salas, L. J.: Analy- 
sis of Ancient Atmosphere, J. Geophys. Res., 78, 5341-5344, doi:10.1029/JC078i024p05341, 1973.

Röckmann, T., Kaiser, J., and Brenninkmeijer, C. A. M.: The isotopic fingerprint of the pre-industrial and the anthropogenic $\mathrm{N}_{2} \mathrm{O}$ source, Atmos. Chem. Phys., 3, 315-323, doi:10.5194/acp-3315-2003, 2003a.

Röckmann, T., Kaiser, J., Brenninkmeijer, C. A. M., and Brand, W. A.: Gas chromatography/isotope-ratio mass spectrometry method for high-precision position-dependent ${ }^{15} \mathrm{~N}$ and ${ }^{18} \mathrm{O}$ measurements of atmospheric $\mathrm{N}_{2} \mathrm{O}$, Rapid Commun. Mass Spectrom., 17, 1897-1908, doi:10.1002/rcm.1132, 2003 b.

Röckmann, T. and Levin, I.: High-precision determination of the changing isotopic composition of atmospheric $\mathrm{N}_{2} \mathrm{O}$ from 1990 to 2002, J. Geophys. Res., 110, D21304, doi:21310.21029/22005JD006066, 2005.

Schäfer, H.: Meterologische Analyse für Spurengasmessungen am Observatorium Izana (Teneriffa) unter Verwendung von Rückwärtstrajektorien, Physik, Universität Mainz, Mainz, 1998.

Schaefer, H., Whiticar, M. J., Brook, E. J., Petrenko, V. V., Ferretti, D., and Severinghaus, J.: Ice Record of $\delta^{13} \mathrm{C}$ for Atmospheric $\mathrm{CH}_{4}$ Across the Younger Dryas-Preboreal Transition, Science, 313, 1109-1112, doi:10.1126/science.1126562, 2006.

Schmitt, J., Schneider, R., and Fischer, H.: A sublimation technique for high-precision measurements of $\delta^{13} \mathrm{CO}_{2}$ and mixing ratios of $\mathrm{CO}_{2}$ and $\mathrm{N}_{2} \mathrm{O}$ from air trapped in ice cores, Atmos. Meas. Tech., 4, 1445-1461, doi:10.5194/amt-4-1445-2011, 2011.

Sowers, T.: $\mathrm{N}_{2} \mathrm{O}$ record spanning the penultimate deglaciation from the Vostok ice core, J. Geophys. Res., 106, 31903-31914, 2001.

Sowers, T.: Late quaternary atmospheric $\mathrm{CH}_{4}$ isotope record suggests marine clathrates are stable, Science, 311, 838-840, doi:10.1126/science.1121235, 2006.

Sowers, T.: Atmospheric $\mathrm{CH}_{4}$ isotope records covering the Holocene period, Quat. Sci. Rev., 29, 213-221, doi:10.1016/j.quascirev.2009.05.023, 2010.
Sowers, T., Rodebaugh, A., Yoshida, N., and Toyoda, S.: Extending records of the isotopic composition of atmospheric $\mathrm{N}_{2} \mathrm{O}$ back to $1800 \mathrm{AD}$ from air trapped in snow at the South Pole and the Greenland Ice Sheet Project II ice core, Global Biogeochem. Cy., 16, 1129, doi:1110.1029/2002GB001911, 2002.

Sowers, T., Alley, R. B., and Jubenville, J.: Ice core records of atmospheric $\mathrm{N}_{2} \mathrm{O}$ covering the last 2000 years, Science, 301, 945948, doi:10.1126/science.1085293, 2003.

Sowers, T., Bernard, S., Aballain, O., Chappellaz, J., Barnola, J. M., and Marik, T.: Records of the $\delta^{13} \mathrm{C}$ of atmospheric $\mathrm{CH}_{4}$ over the last 2 centuries as recorded in Antarctic snow and ice, Global Biogeochem. Cy., 19, 493-503, doi:2010.1029/2004GB002408, 2005.

Spahni, R., Chappellaz, J., Stocker, T. F., Loulergue, L., Hausammann, G., Kawamura, K., Flückiger, J., Schwander, J., Raynayd, D., Masson-Delmotte, V., and Jouzel, J.: Atmospheric methane and nitrous oxide of the late Pleistocene from Antartic ice cores, Science, 310, 1317, doi:10.1126/science.1120132, 2005.

Vigano, I., van Weelden, H., Holzinger, R., Keppler, F., McLeod, A., and Röckmann, T.: Effect of UV radiation and temperature on the emission of methane from plant biomass and structural components, Biogeosciences, 5, 937-947, doi:10.5194/bg5-937-2008, 2008.

Vigano, I., Röckmann, T., Holzinger, R., van Dijk, A., Keppler, F., Greule, M., Brand, W. A., Geilmann, H., and van Weelden, H.: The stable isotope signature of $\mathrm{CH}_{4}$ emitted from plant material under UV irradiation, Atmos. Environ., 43, 5637-5646, doi:5610.1016/j.atmosenv.2009.5607.5046, 2009.

Vigano, I., Holzinger, R., Keppler, F., Greule, M., Brand, W. A., Geilmann, H., van Weelden, H., and Röckmann, T.: Water drives the deuterium content of the $\mathrm{CH}_{4}$ emitted from plants, Geochim. Cosmochim. Act., 74, 3865-3873, doi:10.1016/j.gca.2010.03.030, 2010.

Werner, R. A. and Brand, W. A.: Referencing strategies and techniques in stable isotope ratio analysis, Rapid Commun. Mass Spectrom, 15, 501-519, doi:10.1002/rcm.258, 2001. 